\title{
A brief retraining regulates the persistence and lability of a long-term memory
}

\author{
David Levitan, ${ }^{1,2,4}$ Rachel Twitto, ${ }^{1,2,4}$ Roi Levy, ${ }^{1,2}$ Lisa C. Lyons, ${ }^{3}$ and \\ Abraham J. Susswein ${ }^{1,2,5}$ \\ ${ }^{1}$ The Mina and Everard Goodman Faculty of Life Sciences, Bar Ilan University, Ramat Gan 52900, Israel; ${ }^{2}$ The Leslie and Susan Gonda \\ (Goldschmied) Multidisciplinary Brain Research Center, Bar Ilan University, Ramat Gan 52900, Israel; ${ }^{3}$ Department of Biological \\ Sciences, Florida State University, Tallahassee, Florida 32306, USA
}

\begin{abstract}
An experience extending the persistence of a memory after training Aplysia californica with inedible food also allows a consolidated memory to become sensitive to consolidation blockers. Long-term $(24 \mathrm{~h})$ memory is initiated by $5 \mathrm{~min}$ of training and is dependent on protein synthesis during the first few hours after training. By contrast, a more persistent $(48 \mathrm{~h})$ memory is dependent on a longer training session and on a later round of protein synthesis. When presented $24 \mathrm{~h}$ after training, a 3-min training that produces no memory alone can cause a memory that would have persisted for only $24 \mathrm{~h}$ to persist for $48 \mathrm{~h}$. After a $48 \mathrm{~h}$ memory has been consolidated, 3 min of training also makes the memory sensitive to a protein-synthesis inhibitor. These findings suggest that a function of allowing a consolidated memory to become sensitive to blockers of protein synthesis may be to allow the memory to become more persistent.
\end{abstract}

[Supplemental material is available online at http://www.learnmem.org.]

Long-term memory of an experience is dependent on a consolidation process that follows the experience. Before the memory is consolidated it is labile and can be disrupted (Lechner et al. 1999; Dudai 2004; Alberini and Taubenfeld 2008), particularly by blocking mRNA and protein synthesis (Alberini and Taubenfeld 2008; Klann and Sweatt 2008), which are needed to produce the changes in synaptic structure and function that underlie long-term memory (Sigurdsson et al. 2007; Bailey and Kandel 2008; De Roo et al. 2008). After long-term memory is established by the initial stages of consolidation, later rounds of consolidation may be needed to extend the persistence of the memory (Wittenberg and Tsien 2002; Bekinschtein et al. 2007). Consolidated memories may also be modified when they are retrieved (Dudai 2006; Alberini and Taubenfeld 2008). Retrieving a memory by exposure to the conditioned stimulus, or by re-experiencing aspects of the original training, can destabilize it and initiate an additional protein-synthesis-dependent process of memory stabilization (Nader 2003; Dudai 2006; Alberini and Taubenfeld 2008). The aim of this communication is to explore whether an experience that alone does not cause long-term memory can make a memory more persistent and can also destabilize a consolidated memory and makes it labile.

Training Aplysia californica with inedible food until they stop responding to the food initiates long-term memory that can be measured as a reduction in the time to stop responding. Long-term memory is present 1,2 , and $7 \mathrm{~d}$ after a single training session (Schwarz et al. 1991). We examined some of the parameters of training that lead to persistence of memory by determining whether shorter training sessions also produce a persistent longterm memory.

\footnotetext{
${ }^{4}$ These authors contributed equally to this work.

${ }^{5}$ Corresponding author.

E-mail avy@mail.biu.ac.il; fax 972-3-5352184.

Article is online at http://www.learnmem.org/cgi/doi/10.1101//m.1820010.
}

As in previous studies (Schwarz et al. 1991; Botzer et al. 1998; Lyons et al. 2005), Aplysia californica were trained with inedible food, the seaweed Ulva wrapped in plastic net. This food induced biting, leading to food entering the mouth. Animals then attempted to swallow the food. The netted food cannot be swallowed and it became lodged in the buccal cavity, producing repetitive failed swallowing responses. Food eventually left the buccal cavity. The experimenter continued to hold the food against the lips, inducing further biting responses, entries into the mouth, and failed swallows. As training proceeded many bites failed to cause entry of food into the mouth. When food did enter the mouth it stayed within for progressively shorter periods, eliciting fewer attempted swallows. In all animals, food was in the mouth eliciting failed attempts to swallow for at least $100 \mathrm{sec}$ of the initial training, since previous experience showed that such animals almost always show long-term memory. Animals in which food was not in the mouth for $100 \mathrm{sec}$ during training were discarded. A full training session until animals stop responding to food requires $10-25$ min of training (Fig. 1). Such a training session caused long-term memory measured after $24 \mathrm{~h}$ or after $48 \mathrm{~h}$ (Fig. 1A). Memory was measured by comparing the time to stop responding to inedible food during training to the time to stop responding when animals were tested 24 or $48 \mathrm{~h}$ later, in a procedure identical to that during training. All tests of memory were performed using a blind procedure in which the experimenter was unaware of the previous training procedure.

We examined whether abbreviated training also caused longterm memory. First, we examined long-term memory when training is stopped after $5 \mathrm{~min}$. During the first $5 \mathrm{~min}$ of a full training session, food is in the mouth, and animals are attempting to swallow for a mean of $70 \%$ of the time in the mouth during a full training session. Attempts to swallow are an integral part of the training (Katzoff et al. 2006). We confirmed an earlier finding (Botzer et al. 1998) that a 5-min training produced long-term memory measured $24 \mathrm{~h}$ after the training (Fig. 1B). However, we 


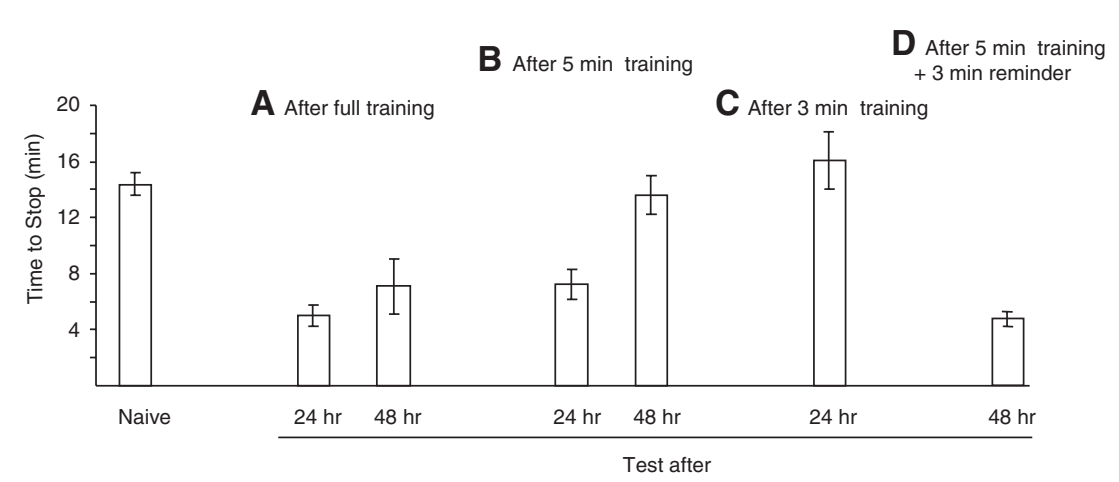

Figure 1. Memory 24 and $48 \mathrm{~h}$ after different training procedures. The figure shows the time to stop responding in a group of naïve animals trained with a full training session (training continued until animals stop responding to food), as well as the time to stop responding on memory trials 24 and $48 \mathrm{~h}$ later $(N=38$ naïve animals [naïve animals were run as controls for the various other groups and data from the naive animals were then combined. There was no significant difference between the various groups of naïve animals: $\left.\left.P=0.405, F_{(5,32)}=1.053\right]\right) ;(A) N=13$ animals tested $24 \mathrm{~h}$ after a full training; $N=6$ animals tested $48 \mathrm{~h}$ after a full training; $(B) N=9$ animals tested $24 \mathrm{~h}$ after a 5-min training; $N=17$ animals tested $48 \mathrm{~h}$ after a 5-min training; (C) $N=14$ animals tested $24 \mathrm{~h}$ after a 3-min training; $(D) N=7$ animals tested $48 \mathrm{~h}$ after a 5 -min training, plus an additional 3-min training $24 \mathrm{~h}$ later. A one-way analysis of variance showed significant differences between the seven groups shown $\left(P<0.001, F_{(6,97)}=11.95\right)$. A post-hoc test (Student-Newman-Keuls, $\alpha=0.05$ ) showed that there were no significant differences between the time to stop in naïve animals and in animals tested $48 \mathrm{~h}$ after a 5 -min training, or in animals tested $24 \mathrm{~h}$ after a 3-min training, indicating that these treatments did not cause memory. By contrast, the times to stop in these three groups were significantly different from that in the other four groups, which were not significantly different from one another. These findings indicate significant memory 24 or $48 \mathrm{~h}$ after a full training, as well as $24 \mathrm{~h}$ after $5 \mathrm{~min}$ of training, and $48 \mathrm{~h}$ after $5 \mathrm{~min}$ of training with $3 \mathrm{~min}$ of reminder training, with no differences in memory after these 4 treatments. Standard errors are shown.

have now found that training animals for only $5 \mathrm{~min}$ did not cause long-term memory measured $48 \mathrm{~h}$ after training (Fig. 1B). A training session that was stopped after 3 min did not give rise to long-term memory measured at $24 \mathrm{~h}$ (Fig. 1C), indicating that the last $2 \mathrm{~min}$ of a 5 -min training are necessary for the production of $24 \mathrm{~h}$ memory. These findings allowed us to examine the possible effects of an experience which itself does not cause memory, 3 min of training on memory persistence and memory lability.

A 5-min training session gives rise to memory after $24 \mathrm{~h}$, but not after $48 \mathrm{~h}$, whereas additional training gives rise to $48 \mathrm{~h}$ memory. Must the additional training take the form of continuing to train animals during the initial training session, or can an additional $3 \mathrm{~min}$ of training that itself does not cause $24 \mathrm{~h}$ memory enhance the effect of a $5 \mathrm{~min}$ of training? To test the ability of a 3-min training to enhance memory, animals were trained with either a full training session, or with a training session that was abbreviated after $5 \mathrm{~min}$. One group of animals trained for $5 \mathrm{~min}$ received an additional 3-min training $24 \mathrm{~h}$ after the initial training, whereas another group did not. Memory was tested $24 \mathrm{~h}$ later, $48 \mathrm{~h}$ after the initial training. Animals receiving a full training, and animals receiving a 5-min training plus a reminder consisting of a 3-min additional training, displayed $48 \mathrm{~h}$ memory (Fig. 1D; for a fuller presentation of this experiment, see Supplemental material), whereas animals receiving only a 5-min training, with no additional training, showed no $48 \mathrm{~h}$ memory. These data show that a 3-min training, which is itself ineffective in producing memory $24 \mathrm{~h}$ later, can lead to significant memory when it follows a 5-min training, which itself would not produce $48 \mathrm{~h}$ memory.

In other learning tasks it has been shown that long-term memory is not a unitary process. An earlier round of protein synthesis is necessary for $24 \mathrm{~h}$ memory, but a more persistent memory $(>24 \mathrm{~h})$, and the synaptic plasticity underlying it, are dependent on later rounds of protein synthesis (Giustetto et al. 2003; did not block $48 \mathrm{~h}$ memory.

Bekinschtein et al. 2007; Miniaci et al. 2008). We therefore examined whether 24 and $48 \mathrm{~h}$ memory differ in their dependence on protein synthesis adjacent to training, or on protein synthesis $6 \mathrm{~h}$ after training. The protein-synthesis inhibitor anisomycin was injected into the hemolymph either $10 \mathrm{~min}$ before training or $6 \mathrm{~h}$ after training. Animals were injected with a $1 \mathrm{cc}$ solution of anisomycin at a concentration that caused a $10 \mu \mathrm{M}$ concentration within the animals. This concentration blocks protein synthesis in ganglia (Schwartz et al. 1971). Controls were injected with $1 \mathrm{cc}$ of artificial seawater (ASW-NaCl $460 \mathrm{mM}, \mathrm{KCl} 10 \mathrm{mM}, \mathrm{CaCl}_{2} 11 \mathrm{mM}$, $\mathrm{MgCl}_{2} 55 \mathrm{mM}$, and $\mathrm{NaHCO}_{3} 5 \mathrm{mM}$ ). Treatment with anisomycin just before training blocked $24 \mathrm{~h}$ memory, but anisomycin treatment $6 \mathrm{~h}$ after training did not prevent the appearance of $24 \mathrm{~h}$ memory, indicating that $24 \mathrm{~h}$ memory is consolidated within the first $6 \mathrm{~h}$ after training (note that Fig. 2A shows the percent change in time to stop responding during the test of memory, with respect to the time to stop during training). By contrast, $48 \mathrm{~h}$ memory was blocked by anisomycin treatment $6 \mathrm{~h}$ after training (Fig. 2B), whereas treatment with ASW

Memory $48 \mathrm{~h}$ after training is dependent on protein synthesis $6 \mathrm{~h}$ after training. As shown above, $3 \mathrm{~min}$ of training can establish $48 \mathrm{~h}$ memory after a 5 -min training that alone is too brief to establish $48 \mathrm{~h}$ memory. Can 3 min of training also establish $48 \mathrm{~h}$ memory after it has been blocked by inhibiting protein synthesis at $6 \mathrm{~h}$ ? To test this possibility, animals were trained with inedible food until they stopped responding, and were then treated with either ASW or anisomycin $6 \mathrm{~h}$ later. One group of animals also received $3 \mathrm{~min}$ of training with inedible food $24 \mathrm{~h}$ after the initial training. When tested $48 \mathrm{~h}$ after training, memory was present in animals treated with ASW and in animals that had received the additional 3-min training, but not in animals receiving only the anisomycin treatment (Fig. 2B). This finding indicates that a 3 -min training that is effective in causing $48 \mathrm{~h}$ memory after 5 min of training can also rescue $48 \mathrm{~h}$ memory after it has been blocked by anisomycin.

If 3 min of training saves a blocked $48 \mathrm{~h}$ memory, it could also amplify an already-formed $48 \mathrm{~h}$ memory. We tested the effect on $48 \mathrm{~h}$ memory of a 3-min training $24 \mathrm{~h}$ after a full training session, which alone produces $48 \mathrm{~h}$ memory. There was no significant difference in memory between animals tested $24 \mathrm{~h}$ after training, and animals receiving a 3-min retraining, and then tested $48 \mathrm{~h}$ after training, indicating that the 3-min training did not affect the already consolidated $48 \mathrm{~h}$ memory (Fig. 3, cf. column 1 and column 3).

The 3-min training does not affect an already-formed $48 \mathrm{~h}$ memory, but does cause effects $24 \mathrm{~h}$ later if the memory is not fully consolidated. Formation of a long-term memory requires protein synthesis, and recalling a consolidated memory can make a memory sensitive to inhibitors of protein synthesis (Nader et al. 2000). Does a 3-min training $24 \mathrm{~h}$ after an initial full training initiate a renewed dependence of $48 \mathrm{~h}$ memory on protein synthesis? Animals were trained to criterion and then subjected to either anisomycin, or ASW, $24 \mathrm{~h}$ later. Both groups then 

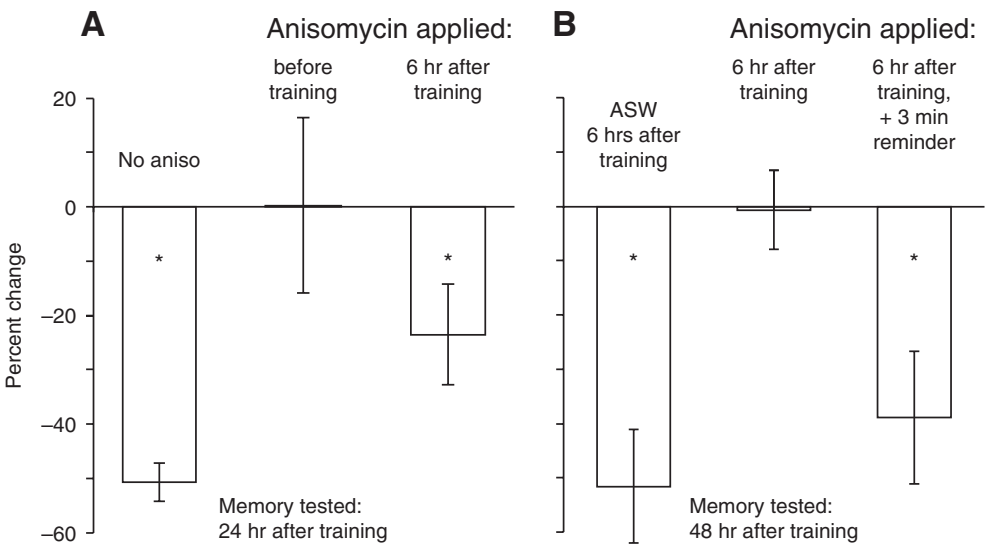

Figure 2. Protein synthesis dependence of 24 and $48 \mathrm{~h}$ memory. Data shows the memory test 24 or $48 \mathrm{~h}$ after training as a percent change [ - ([train-test]/train) $\times 100]$ from the initial training session. Al tests of memory were after a full training session until animals stopped responding to the food. Memory was tested via two-tailed paired $t$-tests, in which the time to stop responding in a given animal during the initial training was compared with the time to stop responding 24 or $48 \mathrm{~h}$ later, when animals were tested. A significant decrease in the time to stop responding was used as an indicator of memory. Treatments showing such a decrease are marked (*). Standard errors are shown. (A) Anisomycin treatment blocks $24 \mathrm{~h}$ memory when applied just before training, but not when applied $6 \mathrm{~h}$ after training. Control animals $(N=8)$ not treated with anisomycin displayed significant $24 \mathrm{~h}$ memory $(P<0.001$, $\left.t_{(7)}=10.15\right)$. Anisomycin applied $10 \mathrm{~min}$ before the training $(N=9)$ blocked memory, as shown by a lack of significant decrease in the time to stop between the initial training and the test after $24 \mathrm{~h}$ $\left(P=0.96, t_{(8)}=0.05\right)$. By contrast, application of anisomycin $6 \mathrm{~h}$ after the initial training $(N=7)$ did not block memory measured $24 \mathrm{~h}$ after training, as shown by significant savings after $24 \mathrm{~h}(P=0.05$, $\left.t_{(6)}=2.45\right)$. (B) Forty-eight hour memory is dependent on a later stage of protein synthesis. Anisomycin $(N=26)$, but not ASW $(N=5)$ applied $6 \mathrm{~h}$ after training blocks $48 \mathrm{~h}$ memory, as shown by significant memory after treatment with ASW $\left(P=0.007, t_{(4)}=5.08\right)$ but not with anisomycin $\left(P=0.49, t_{(25)}=0.69\right)$. However, a 3-min reminder training $24 \mathrm{~h}$ after the training $(N=12)$ rescues $48 \mathrm{~h}$ memory after it was blocked by anisomycin treatment $6 \mathrm{~h}$ after training $\left(P=0.01, t_{(11)}=2.93\right)$.

received a 3-min reminder training 10 min later. Memory was then assessed $24 \mathrm{~h}$ later ( $48 \mathrm{~h}$ after initial training). There was significant memory $48 \mathrm{~h}$ after the training after treatment with ASW, but not after treatment with anisomycin, indicating that the 3 -min reminder training restored the ability of anisomycin to block memory (Fig. 3).

Our data have shown that 3 min of training with inedible food alone does not produce long-term memory (Fig. 1), and does not amplify an already established $48 \mathrm{~h}$ memory (Fig. 3). Nonetheless, $3 \mathrm{~min}$ of training induces a protein-synthesisdependent state in which memory can be modified (Figs. 2, 3). After a previous training leading to only $24 \mathrm{~h}$ memory (Fig. 1), or after a treatment blocking $48 \mathrm{~h}$ memory, the 3-min training makes the memory more persistent (Fig. 2). In addition, after a $48 \mathrm{~h}$ memory has already been consolidated, $3 \mathrm{~min}$ of training makes the memory labile, so that it can be blocked by inhibitors of protein synthesis (Fig. 3).

Reconsolidation is a process by which a consolidated memory returns to a protein-synthesis-dependent labile state by retrieving the memory (e.g., Nader et al. 2000; Sangha et al. 2003; Kemenes et al. 2006). In learning that food is inedible 3 min of training makes the memory labile. There has been much speculation on the possible function of memory reconsolidation. It has been suggested that the destabilization of memory by retrieval could function as a means to update and modify the magnitude and the persistence of the original memory trace (Dudai 2002, 2006). There is good evidence that reconsolidation can update (Rodriguez-Ortiz et al. 2005; Morris et al. 2006), strengthen (Frenkel et al. 2005; Tronson et al. 2006; Lee 2008), or modify (Rossato et al. 2006) memories, as well as block them (Nader et al. 2000), but the possible role of reconsolidation in of training is absent (Fig. 1), or when the later wave of protein synthesis is blocked (Fig. 2). This finding suggests that the initial experience required to establish $48 \mathrm{~h}$ memory, as well as the wave of protein synthesis elicited by this experience, can be deferred. A later experience, and a later wave of protein synthesis, can substitute for the absence of experience in the initial training, or for the blocked wave of protein synthesis. In addition to creating a more persistent memory, a 3-min retraining also makes a consolidated memory sensitive to blocking by inhibitors of protein synthesis (Fig. 3). Thus, a function of experiences that permit reconsolidation may also be to extend the persistence of a memory.

In our study we cannot exclude the possibility that the 3-min retraining does more than just retrieve memory, and thereby make it labile. The increased persistence of memory could be caused by processes initiated by the 3-min training, such as increased consolidation, that are not related to the ability of the added training to make the memory labile. Indeed, previous studies have suggested that memory consolidation and reconsolidation may utilize different molecular mechanisms (Taubenfeld et al. 2001; Lee et al. 2004; Alberini 2005). The different molecular mechanisms activated by consolidation or reconsolidation have been used to classify the process by which retrieval affects memory, although use of the molecular markers to classify a behavioral process is controversial (Nader et al. 2005). Such studies have shown that changing a memory when it is retrieved sometimes utilizes a molecular mechanism for consolidation (Tronel et al. 2005), and sometimes for reconsolidation (Lee 2008). In the learning task utilized we have not examined separate molecular markers for consolidation and reconsolidation, raising the possibility that a 3-min retraining affects persistence by 


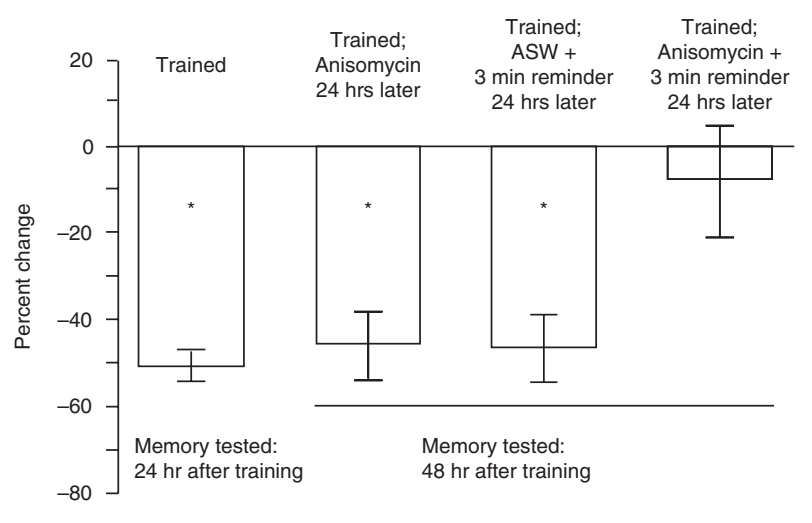

Figure 3. Brief training makes memory labile. Twenty-four hours after training with inedible food, animals were treated with anisomycin, or with ASW. The animals treated with ASW $(N=9)$, as well as one of the two groups treated with anisomycin $(N=9)$, were also given a 3-min training session $10 \mathrm{~min}$ later. Memory was then tested again $24 \mathrm{~h}$ later, $48 \mathrm{~h}$ after the training, by comparing the time to stop measured $48 \mathrm{~h}$ after training with the time to stop measured during the original training session, using a two-tailed paired $t$-test. A significant decrease in the time to stop responding was used as an indicator of memory. Data are also shown for $24 \mathrm{~h}$ memory after a full training session, to allow a test of whether a 3-min retraining at $24 \mathrm{~h}$ improves memory tested at $48 \mathrm{~h}$. Treatment with anisomycin alone $(N=8)$ did not block $48 \mathrm{~h}$ memory $\left(P=0.002, t_{(7)}=4.66\right)$. The 3 -min reminder training plus treatment with ASW also did not block $48 \mathrm{~h}$ memory $\left(P=0.001, t_{(8)}=5.02\right)$. By contrast, when the 3-min reminder training was preceded by anisomycin treatment, there was no significant difference between training and the $48 \mathrm{~h}$ test $\left(P=0.27, t_{(8)}=1.18\right)$, indicating that the 3 -min reminder allowed the anisomycin to block $48 \mathrm{~h}$ memory. Note that there is also no significant difference in savings after the 3-min training following ASW treatment and $24 \mathrm{~h}$ memory following training $\left(P=0.13, t_{(10)}=\right.$ $1.63)$, indicating that the 3 -min training on day 2 alone did not affect memory.

activating molecular mechanisms that are specifically associated with a separate round of consolidation, rather than activating reconsolidation.

Memory reconsolidation also affects a number of other molluscan learning paradigms (Sekiguchi et al. 1997; Sangha et al. 2003; Gainutdinova et al. 2005; Kemenes et al. 2006). In some, the memory becomes labile when animals are exposed to a CS alone, which does not itself create memory, whereas in others the memory becomes labile only when the CS is paired with an unconditioned stimulus (US), as in the original training (see Eisenhardt and Stollhoff 2008). In our experiments, memory was made labile by a second training session, which was shorter than that needed to itself create memory. It will be of interest to determine whether components of the experience alone in which animals learn that food is inedible do not give rise to memory, such as lip stimulation alone (Schwarz et al. 1988), can also give rise to reconsolidation, although they would not cause a more persistent memory.

Where in the Aplysia nervous system are molecular changes related to reconsolidation and the persistence of memory localized? The earliest molecular changes leading to long-term memory that a food is inedible (e.g., increased expression of C/EBP and sensorin), are localized to the buccal ganglia, specifically to a population of mechanoafferents (Levitan et al. 2008a,b). It is possible that the later molecular changes leading to a persistent memory are also localized to these neurons, similar to the localization to the same sensory neurons of earlier and later molecular events leading to long-term facilitation underlying sensitization in Aplysia (Miniaci et al. 2008). However, it is also possible that the later phases of consolidation, and reconsolidation, may arise by molecular changes localized to other sites with the Aplysia nervous system, similar to the movement of earlier and later phases on long-term declarative memories from the hippocampus to the neocortex (Squire and Kandel 1999). Future studies will need to examine these points.

\section{Acknowledgments}

The research was supported by Grant Nos. 357/02-17.2 and 506/ 09 from the Israel Science Foundation (A.J.S.), and by NIMH 5R01MH81012 (L.C.L.).

\section{References}

Alberini CM. 2005. Mechanisms of memory stabilization: Are consolidation and reconsolidation similar or distinct processes? Trends Neurosci 28: 51-56.

Alberini CM, Taubenfeld SM. 2008. Memory reconsolidation. In Learning and memory - a comprehensive reference (ed. JH Byrne), Vol. 4,

Molecular mechanisms of memory (ed. Sweatt D), pp. 235-243. Academic, New York.

Bailey CH, Kandel ER. 2008. Synaptic remodeling, synaptic growth and the storage of long-term memory in Aplysia. Prog Brain Res 169: 179-198.

Bekinschtein P, Cammarota M, Igaz LM, Bevilaqua LR, Izquierdo I, Medina JH. 2007. Persistence of long-term memory storage requires a late protein- synthesis- and BDNF-dependent phase in the hippocampus. Neuron 53: 261-277.

Botzer D, Markovich S, Susswein AJ. 1998. Multiple memory processes following training that a food is inedible in Aplysia. Learn Mem 5: 204-219.

De Roo M, Klauser P, Garcia PM, Poglia L, Muller D. 2008. Spine dynamics and synapse remodeling during LTP and memory processes. Prog Brain Res 169: 199-207.

Dudai Y. 2002. Molecular bases of long-term memories: A question of persistence. Curr Opin Neurobiol 12: 211-216.

Dudai Y. 2004. The neurobiology of consolidations, or, how stable is the engram? Annu Rev Psychol 55: 51-86.

Dudai Y. 2006. Reconsolidation: The advantage of being refocused. Curr Opin Neurobiol 16: 174-178.

Eisenberg M, Kobilo T, Berman DE, Dudai Y. 2003. Stability of retrieved memory: Inverse correlation with trace dominance. Science 301: 1102-1104.

Eisenhardt D, Stollhoff N. 2008. Reconsolidation in invertebrates. In Learning and memory - a comprehensive reference (ed. JH Byrne), Vol. 1, Learning theory and behaviour (ed. R Menzel), pp. 529-548. Academic, New York.

Frenkel L, Maldonado H, Delorenzi A. 2005. Memory strengthening by a real-life episode during reconsolidation: An outcome of water deprivation via brain angiotensin II. Eur J Neurosci 22: 1757-1766.

Gainutdinova TH, Tagirova RR, Ismailova AI, Muranova LN, Samarova EI, Gainutdinov KL, Balaban PM. 2005. Reconsolidation of a context long-term memory in the terrestrial snail requires protein synthesis. Learn Mem 12: 620-625.

Giustetto M, Hegde AN, Si K, Casadio A, Inokuchi K, Pei W, Kandel ER, Schwartz JH. 2003. Axonal transport of eukaryotic translation elongation factor $1 \alpha$ mRNA couples transcription in the nucleus to long-term facilitation at the synapse. Proc Natl Acad Sci USA 100: $13680-13685$.

Katzoff A, Ben-Gedalya T, Hurwitz I, Miller N, Susswein YZ, Susswein AJ. 2006. Nitric oxide signals that Aplysia have attempted to eat, a necessary component of memory formation after learning that food is inedible. J Neurophysiol 96: 1247-1257.

Klann E, Sweatt JD. 2008. Altered protein synthesis is a trigger for long-term memory formation. Neurobiol Learn Mem 89: 247-259.

Kemenes G, Kemenes I, Michel M, Papp A, Müller U. 2006. Phasedependent molecular requirements for memory reconsolidation: Differential roles for protein synthesis and protein kinase A activity. J Neurosci 26: 6298-6302.

Lechner HA, Squire LR, Byrne JH. 1999. 100 years of consolidation-remembering Müller and Pilzecker. Learn Mem 6: $77-87$.

Lee JL. 2008. Memory reconsolidation mediates the strengthening of memories by additional learning. Nat Neurosci 11: 1264-1266.

Lee JL, Everitt BJ, Thomas KL. 2004. Independent cellular processes for hippocampal memory consolidation and reconsolidation. Science 304: $839-843$. 
Levitan D, Lyons LC, Perelman A, Green CL, Motro B, Eskin A, Susswein AJ. 2008a. Training with inedible food in Aplysia causes expression of $\mathrm{C} / \mathrm{EBP}$ in the buccal but not cerebral ganglion. Learn Mem 15: $412-416$.

Levitan D, Saada R, Motro B, Susswein AJ. 2008b. Localization of increased ApC/EBP expression to buccal ganglia sensory neurons after training with inedible food in Aplysia. Program No. 880.6, Neuroscience Meeting Planner. Society for Neuroscience, Washington, DC.

Lyons LC, Rawashdeh O, Katzoff A, Susswein AJ, Eskin A. 2005. Circadian modulation of complex learning in diurnal and nocturnal Aplysia. Proc Natl Acad Sci USA 102: 12589-12594.

Miniaci MC, Kim JH, Puthanveettil SV, Si K, Zhu H, Kandel ER, Bailey CH. 2008. Sustained CPEB-dependent local protein synthesis is required to stabilize synaptic growth for persistence of long-term facilitation in Aplysia. Neuron 59: 1024-1036.

Morris RG, Inglis J, Ainge JA, Olverman HJ, Tulloch J, Dudai Y, Kelly PA. 2006. Memory reconsolidation: Sensitivity of spatial memory to inhibition of protein synthesis in dorsal hippocampus during encoding and retrieval. Neuron 50: 479-489.

Nader K. 2003. Memory traces unbound. Trends Neurosci 26: 65-72.

Nader K, Schafe GE, Le Doux JE. 2000. Fear memories require protein synthesis in the amygdala for reconsolidation after retrieval. Nature 406: $722-726$.

Nader K, Hardt O, Wang SH. 2005. Response to Alberini: Right answer, wrong question. Trends Neurosci 28: 346-347.

Pedreira ME, Maldonado H. 2003. Protein synthesis subserves reconsolidation or extinction depending on reminder duration. Neuron 38: $863-869$.

Rodriguez-Ortiz CJ, De la Cruz V, Gutiérrez R, Bermudez-Rattoni F. 2005. Protein synthesis underlies post-retrieval memory consolidation to a restricted degree only when updated information is obtained. Learn Mem 12: 533-537.

Rossato JI, Bevilaqua LR, Medina JH, Izquierdo I, Cammarota M. 2006. Retrieval induces hippocampal-dependent reconsolidation of spatial memory. Learn Mem 13: 431-440.

Sangha S, Scheibenstock A, Lukowiak K. 2003. Reconsolidation of a long-term memory in Lymnaea requires new protein and RNA synthesis and the soma of right pedal dorsal 1. J Neurosci 23: 8034-8040.

Schwartz JH, Castellucci VF, Kandel ER. 1971. Functioning of identified neurons and synapses in abdominal ganglion of Aplysia in absence of protein synthesis. J Neurophysiol 34: 939-953.

Schwarz M, Markovich S, Susswein AJ. 1988. Parametric features of inhibition of feeding in Aplysia by associative learning, satiation and sustained lip stimulation. Behav Neurosci 102: $124-133$.

Schwarz M, Feldman E, Susswein AJ. 1991. Variables affecting long-term memory of learning that a food is inedible in Aplysia. Behav Neurosci 105: 193-201.

Sekiguchi T, Yamada A, Suzuki H. 1997. Reactivation-dependent changes in memory states in the terrestrial slug Limax flavus. Learn Mem 4: 356-364.

Sigurdsson T, Doyère V, Cain CK, LeDoux JE. 2007. Long-term potentiation in the amygdala: A cellular mechanism of fear learning and memory. Neuropharmacol 52: 215-227.

Spear NE. 1973. Retrieval of memory in animals. Psychol Rev 80: $163-194$.

Squire LR, Kandel ER. 1999. Memory: From mind to molecules. Scientific American Library, New York.

Taubenfeld SM, Milekic MH, Monti B, Alberini CM. 2001. The consolidation of new but not reactivated memory requires hippocampal C/EBPß. Nat Neurosci 4: 813-818.

Tronel S, Milekic MH, Alberini CM. 2005. Linking new information to a reactivated memory requires consolidation and not reconsolidation mechanisms. PLoS Biol 3: e293. doi: 10.1371/journal.pbio.0030293.

Tronson NC, Wiseman SL, Olausson P, Taylor JR. 2006. Bidirectional behavioral plasticity of memory reconsolidation depends on amygdalar protein kinase A. Nat Neurosci 9: 167-169.

Wittenberg GM, Tsien JZ. 2002. An emerging molecular and cellular framework for memory processing by the hippocampus. Trends Neurosci 25: 501-505.

Received March 28, 2010; accepted in revised form June 15, 2010. 


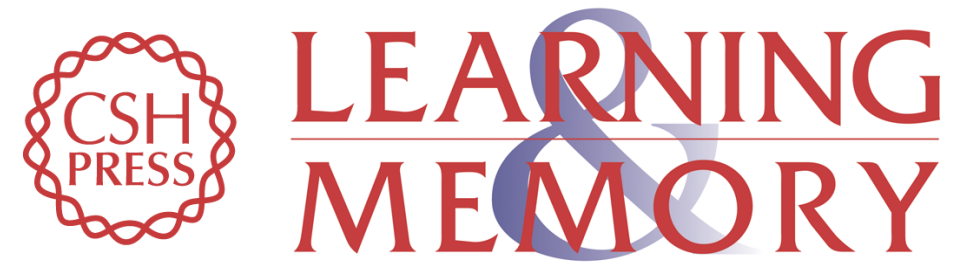

\section{A brief retraining regulates the persistence and lability of a long-term memory}

David Levitan, Rachel Twitto, Roi Levy, et al.

Learn. Mem. 2010, 17:

Access the most recent version at doi:10.1101//m.1820010

Supplemental http://learnmem.cshlp.org/content/suppl/2010/08/03/17.8.402.DC1
Material

References This article cites 39 articles, 13 of which can be accessed free at: http://learnmem.cshlp.org/content/17/8/402.full.html\#ref-list-1

License

Email Alerting Receive free email alerts when new articles cite this article - sign up in the box at the Service top right corner of the article or click here. 